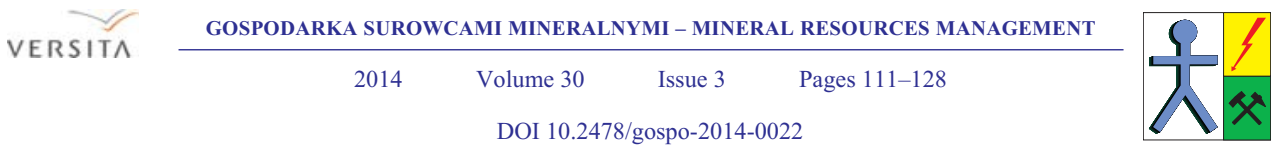

\title{
Laboratoryjne studium porównawcze środków chemicznych stosowanych w zabiegach ograniczania dopływu wody do odwiertów gazowych
}

\begin{abstract}
Wprowadzenie
Jednym z problemów techniczno-ekonomicznych podczas eksploatacji złóż węglowodorów jest wysoka produkcja wody z odwiertów ropnych lub gazowych. Ma to decydujący wpływ na ekonomikę procesu wydobycia. Szacuje się, że produkcja wody z odwiertów ropnych i gazowych każdego roku kosztuje przemysł naftowy ponad 45 miliardów dolarów. Kwota ta zawiera koszt wydobycia wody na powierzchnię oraz jej utylizacji lub ponownego zatłoczenia do złoża, jak również wszystkich instalacji naziemnych, niezbędnych podczas wydobywania wody złożowej z odwiertów produkujących węglowodory, oraz koszty związane ze staraniami, by wszystkie niezbędne procesy nie wpływały negatywnie na środowisko naturalne (Curtice i Dalrymple 2004). Niniejsza publikacja jest kontynuacją prac prowadzonych w Instytucie Nafty i Gazu w Krakowie, związanych z modyfikacją przepuszczalności skał kolektorskich za pomocą biożeli (Falkowicz i in. 2009) oraz dostępnych na rynku polimerów i mikrożeli wytypowanych do selektywnego odcinania dopływu wody złożowej do odwiertów gazowych i ropnych (Falkowicz i in. 2011). W świetle uzyskanych wyników badań laboratoryjnych, celowa jest odpowiedź na pytanie: „czy te wymienione zabiegi, znane z literatury angielskiej pod nazwą RPM (Relative Permeability Modification),

* Dr inż., *** Mgr inż., Instytut Nafty i Gazu Kraków - Państwowy Instytut Badawczy; e-mail: falkowicz@inig.pl; cicha@inig.pl

** Prof. dr hab. inż., AGH Akademia Górniczo-Hutnicza w Krakowie, Wydział Wiertnictwa, Nafty i Gazu, Katedra Inżynierii Naftowej; e-mail: dubiel@wnaft.agh.edu.pl
\end{abstract}


mogłyby być efektywnie zastosowane do selektywnego odcinania dopływu wody złożowej do odwiertów wydobywczych gazu ziemnego w warunkach geologiczno-złożowych występujących na przedgórzu Karpat?"

\section{Analiza skuteczności wybranych zabiegów RPM}

W zagranicznej literaturze fachowej zauważyć można dwie teorie, dotyczące działania cieczy RPM w skale złożowej. Jedna z nich opiera się na założeniu selektywnego przepływu cieczy zabiegowej przez ośrodek porowaty, według drugiej teorii istotne są zjawiska zachodzące na ścianach porów skały złożowej. Pierwsza z teorii zakłada, że wewnątrz ośrodka porowatego rozdzielone są strumienie przepływu dla ropy i wody lub gazu i wody. Zatłaczany żel polimerowy zazwyczaj wybiera ścieżki preferencyjne wody i tym samym odcina jej dostęp do odwiertu. Druga teoria opiera się na założeniu, że zatłoczony żel tworzy zaadsorbowany film na ścianach porów, a tym samym drastycznie zmienia warunki przepływu dwufazowego (Zaitoun i in. 1999, 2001). W przypadku tej ostatniej teorii istnieją dwie hipotezy: pierwsza zakłada, że żel jest bardzo zwięzły i trwały, druga - że zaadsorbowany film polimerowy może zostać ściśnięty przez przepływ ropy poprzez kanały porów skały zbiornikowej. Dwa czynniki mają zasadniczy wpływ na powodzenie zabiegu ograniczenia dopływu wody złożowej do odwiertu: odpowiedni wybór odwiertu oraz dobór receptury cieczy RPM. Skład użytej cieczy zabiegowej warunkują oddziaływania pomiędzy skałą złożową i polimerem (siły dyspersyjne Londona, oddziaływania elektrostatyczne van der Waalsa, zawartość iłu, wpływ sił jonowych oraz w odwiertach ropnych hydrofilność skały złożowej) (Mennella i in. 1999).

Pierwsze prace nad modyfikatorami przepuszczalności RPM prowadzone były w odwiertach ropnych, a pod koniec lat osiemdziesiątych kolejno rozszerzone zostały na odwierty gazowe na złożach gazu ziemnego i podziemnych magazynach gazu. Institut Francais de Petrole (IFP) przeprowadził ponad 100 takich zabiegów RPM (Zaitoun i in. 1999). Stosowane przez IFP ciecze przygotowywane są na bazie nietoksycznych wysokomolekularnych rozpuszczalnych $\mathrm{w}$ wodzie polimerów, które pęcznieją w złożu lub są sieciowane in situ. W zależności od warunków złożowych zastosowane były trzy rodzaje cieczy (Zaitoun i in. 1992a, 1999).

Pierwsza z nich to kopolimer akrylamid-akrylan, charakteryzujący się szczególnymi właściwościami. Cząsteczki polimeru ulegają kurczeniu przy wysokim stopniu zasolenia, natomiast spadek zasolenia powoduje pęcznienie cząsteczek polimeru. Jest to ciecz odpowiednia dla złóż o niskim zasoleniu i temperaturze, które zatłaczane są w solance o wysokim stopniu zasolenia. Po wznowieniu produkcji woda złożowa o niskim zasoleniu wymienia stopniowo zatłoczoną solankę, powodując pęcznienie polimeru zaadsorbowanego na ścianach porów. Zaletami tego typu cieczy jest niska lepkość podczas zatłaczania, wysoki stopień adsorpcji oraz wysoki spadek przepuszczalności skał dla wody.

W drugim przypadku stosowane są niejonowe poliakrylamidy. Niejonowy charakter molekuł polimeru sprawia, że jest on niewrażliwy na skład solanki. W zależności od stopnia 
mineralizacji solanki, ciecze te zatłaczane są z silnie zasadowymi czynnikami, powodującymi pęcznienie (hydrolizę polimerów in situ), lub z organicznym czynnikiem sieciującym (glioxal). W wysokich temperaturach poliakrylamid może być sieciowany za pomocą mleczanu cyrkonu. W porównaniu do kopolimeru akrylamid-akrylan ciecz ta charakteryzuje się niższą lepkością oraz wyższą zdolnością adsorpcyjną.

Trzecia ciecz to skleroglukan (wysokocząsteczkowy niejonowy polisacharyd). Polimer ten wykazuje szereg zalet. Zmiana zasolenia nie wpływa na lepkość polimeru, ponadto przez charakter niejonowy wykazuje dużą zdolność adsorpcyjną na większości skał zbiornikowych oraz jest stabilny termicznie w temperaturze do $105^{\circ} \mathrm{C}$ przez kilka miesięcy. Ciecz ta jest odpowiednia do zabiegów przeprowadzanych na złożach o wysokiej temperaturze złożowej. Pęcznienie polimeru zachodzi poprzez siłę ścinającą wywołaną wysokim tempem zatłaczania lub również przez sieciowanie za pomocą mleczanu cyrkonu oraz innego organometalicznego czynnika sieciującego. Czynnikiem warunkującym powstanie żelu jest podwyższona temperatura, przez co wyeliminowane zostało ryzyko przedwczesnego przejścia zolu w żel.

Zabiegi z zastosowaniem wyżej wymienionych cieczy były wykonane w różnych warunkach, między innymi w odwiertach gazowych, horyzontalnych odwiertach produkujących ciężką ropę, odwiertach morskich i innych. Pierwsze zabiegi przeprowadzono w latach 1986-1989 na odwiertach gazowych VA-48, VA-49 (Velaine, Francja), morskim odwiercie ropnym (BAM 16, Gabon) oraz odwiercie horyzontalnym produkującym rope 11-15A (Pelican Lake, Kanada) (Zaitoun i in. 1992b). W przypadku odwiertów gazowych, w których skałę złożową stanowi piaskowiec, przeprowadzony w 1986 roku zabieg z zastosowaniem zhydrolizowanych poliakrylamidów znacznie obniżył wykładnik wodny, który pozostał na niskim poziomie przez kolejne trzy lata eksploatacji. Analogiczny zabieg wykonany na odwiercie, w którym skałą kolektorską jest warstwowy wapień, spowodował $33 \%$ redukcje produkcji gazu przy niezmienionej produkcji wody. W połowie 1989 roku został przeprowadzony zabieg, w którym ciecz zabiegową stanowił roztwór niejonowego polimeru. Zabieg zatłoczenia $60 \mathrm{~m}^{3}$ wykonano na horyzontalnym odwiercie 11-15A. By umożliwić pęcznienie polimeru in situ odwiert był zamknięty przez pięć dni. Przez dwa lata po przeprowadzonym zabiegu odnotowano o $40 \%$ niższą produkcję wody niż przed zabiegiem (Zaitoun i in. 1992b).

Na początku lat dziewięćdziesiątych w IFP oraz ITE (Technical University Clausthal, Niemcy) podjęto wspólne badania mające na celu skomponowanie cieczy RPM ograniczającej dopływ wody do odwiertów gazowych. Poprzedzone testami laboratoryjnymi zabiegi na złożu w północnych Niemczech wykazały skuteczność częściowo sulfonowanego terpolimeru akrylamidowego o stosunkowo niskiej masie czasteczkowej. Ciecz tego typu ma doskonałą rozpuszczalność we wszystkich typach solanek złożowych oraz dobrą stabilność termalną $\mathrm{w}$ temperaturze do $150^{\circ} \mathrm{C}$. Przewaga tych polimerów nad innymi konkurencyjnymi produktami staje się oczywista, gdy temperatura przekracza $80^{\circ} \mathrm{C}$, a przepuszczalność skał dla gazu jest mniejsza niż $10^{-13} \mathrm{~m}^{2}$ (około100 mD) (Ranjbar i in. 1995). Testy złożowe wykazały ponadto, że selektywność adsorpcji tego typu polimeru pozostaje niezmieniona 
nawet $\mathrm{w}$ wysokotemperaturowych odwiertach gazowych (około $130^{\circ} \mathrm{C}$ ) o niskiej przepuszczalności rzędu $10^{-14} \mathrm{~m}^{2}$ (około $10 \mathrm{mD}$ ) (Ranjbar i Kohler 1993). Podobne wyniki uzyskano również na wysokotemperaturowym odwiercie gazowym Salzwedel 85, na którym obserwowano migrację wody przez częściowo sczerpaną warstwę gazonośną oraz odwiercie na magazynie gazu Buchholz P 17, w którym produkcja wody występowała okresowo pod koniec eksploatacji. Z wyników badań przeprowadzonych w DBI-GUT we Freibergu, IFP w Paryżu oraz ITE w Clausthal jednoznacznie wynika, że dla odwiertów niskotemperaturowych (np. $34^{\circ} \mathrm{C}$ ) o wysokiej przepuszczalności 5,6 $\times 10^{-13} \mathrm{~m}^{2}$ (około $560 \mathrm{mD}$ ), najlepszym rozwiązaniem jest użycie kopolimeru o charakterze kationowym, natomiast dla wysokotemperaturowych odwiertów (np. $122^{\circ} \mathrm{C}$ ) o niskiej przepuszczalności $10^{-14} \mathrm{~m}^{2}$ $(10 \mathrm{mD})$ wskazane jest użycie anionowego terpolimeru. Ponadto ustalono, że aby zabieg się powiódł konieczne jest by promień strefy penetracji cieczy zabiegowej wynosił od 5 do 10 metrów (Pusch i in. 1995).

Równolegle podobne prace przeprowadzono w Chinach oraz we Włoszech. Zabiegi wykonane na odwiertach znajdujących się na bloku W złoża Lunyu o średniej przepuszczalności $5 \times 10^{-14} \mathrm{~m}^{2}(50 \mathrm{mD}) \mathrm{i}$ temperaturze rzędu $72^{\circ} \mathrm{C}$ wykazały, że zabieg z zastosowaniem wytypowanego poprzez testy laboratoryjne polimeru HPAM-2 zmniejsza wykładnik wodny o około $60-70 \%$ oraz w przeciagu 1,5 roku zwiększa wydobycie gazu o około 10-15\% (Tielong i in. 1998). W latach dziewięćdziesiątych XX wieku wykonano również zabieg na złożu gazu East High Island 285 (Kolorado, USA), podczas którego przy zastosowaniu cieczy na bazie polimeru sieciowanego anionowym poliakryloamidem, zmniejszył się wykładnik wodny o około 92\% w stosunku do jego wartości sprzed zabiegu (Dovan $i$ in. 1994). Podobne wyniki uzyskane zostały w magazynie gazu Sait-Clair-sur Epte (odwiert $\mathrm{VN}-21$ ).

Na początku obecnego stulecia wprowadzono ciecze selektywnie modyfikujące przepuszczalność skały zbiornikowej w postaci mikrożeli, które charakteryzują się wyjątkowymi właściwościami mechanicznymi i chemicznymi oraz stabilnością termiczną (Rousseau i in. 2005). Pseudoplastyczne właściwości reologiczne ułatwiają zatłaczanie tych cieczy, a redukcja przepuszczalności dla wody może być osiągnięta poprzez kontrolę warstwy zaadsorbowanej na powierzchni porów skały zbiornikowej. Kontrola ta może odbywać się poprzez odpowiedni dobór cząsteczek mikrożelu lub kontrolę stężenia cieczy zabiegowej. Mechanizm redukcji przepuszczalności skały dla wody polega na adsorpcji na powierzchni porów grubej warstwy żelu, która pod wpływem sił kapilarnych ulega zniszczeniu blokując ścieżki preferencyjne wody. Przepuszczalność skał dla węglowodorów pozostaje niezmieniona. Wyniki badań laboratoryjnych zostały potwierdzone podczas zabiegu. Zatłoczony mikrożel o rozmiarze cząstek rzędu $2 \mu \mathrm{m}$ został umiejscowiony w warstwach skały złożowej o najwyższej przepuszczalności, które odpowiadają za produkcję wody, a tym samym znacznie obniżył tzw. wykładnik wodno-gazowy (WWG). Penetracja cieczy zabiegowej w strefy o średniej lub niskiej przepuszczalności była znikoma (Zaitoun i in. 2007). Od 2001 roku szereg otworów w podziemnych magazynach gazu zostało poddanych zabiegom z zastosowaniem cieczy RPM na bazie polimerów lub mikrożeli. Cząsteczki 
polimerów mają rozmiar rzędu $0,3 \mu \mathrm{m}$, co ogranicza grubość zaadsorbowanej warstwy. Z kolei rozmiar cząsteczek mikrożeli jest z zakresu od $0,3-2 \mu \mathrm{m}$, co daje możliwość tworzenia grubszych warstw. Mikrożele są również bardziej stabilne i można je stosować w otworach o trudnych warunkach złożowych oraz w temperaturach do $165^{\circ} \mathrm{C}$. Wyniki zabiegów wykazały również ograniczenie piaszczenia w odwiertach. Nie jest to zjawisko wtórne, gdyż zabieg z użyciem cieczy RPM w odwiertach produkujących znikome ilości wody ograniczał piaszczenie, natomiast nie wpływał na wykładnik wodny. Ponadto potwierdzono, że gdy efektywność zabiegu spada możliwy jest kolejny zabieg tego samego typu, który da równie pozytywne efekty (Zaitoun 2007). W 2007 roku na kilku złożach gazu w Ameryce Południowej zastosowano nowej generacji ciecz na bazie hydrofobowych wodnych roztworów polimerów, która może być zatłoczona w całości lub sekwencyjnie do wybranej strefy złoża w zależności od warunków złożowych, dostępnego sprzętu oraz czynników ekonomicznych. Ponadto zastosowanie hydrofobowych wodnych roztworów polimerów nowej generacji nie wymaga zamknięcia otworu (Gutierrez i in. 2007).

\section{Podstawowe kryteria typowania odwiertów wydobywczych do zabiegów RPM}

Odwierty wydobywcze planowane do zabiegów RPM powinny spełniać następujące podstawowe kryteria (Zaitoun $\mathrm{i}$ in. 2007):

- temperatura złoża powinna być niższa od $160^{\circ} \mathrm{C}$,

- wartość przepuszczalność skał kolektorskich powinna zawierać się w przedziale pomiędzy $10^{-16} \mathrm{~m}^{2}$ (około $0,1 \mathrm{mD}$ ) a $6 \times 10^{-12} \mathrm{~m}^{2}$ (około $6000 \mathrm{mD}$ ),

- w złożu wielowarstwowym nie może być przepływów pomiędzy warstwami,

- pozostałe do wydobycia zasoby węglowodorów muszą zapewnić ekonomicznie sensowny okres eksploatacji złoża po zabiegu RPM.

Wyboru konkretnego rodzaju (produktu) środka chemicznego do zastosowania w zabiegach RPM w konkretnym odwiercie dokonuje się, uwzględniając:

- pH wody złożowej i jej zasolenie,

- temperaturę złożowa,

- rodzaj skał kolektorskich (jednorodny piaskowiec, kolektor szczelinowy, obecność warstw wysoko przepuszczalnych i innych cech wpływających na dysproporcje przepuszczalności skał), a także rodzaju wcześniej wykonanych zabiegów stymulacyjnych, takich jak np. szczelinowanie hydrauliczne skał,

- wyniki badań laboratoryjnych wytypowanego środka chemicznego na rdzeniach dla zbliżonych warunków złożowych.

Ze względu na dużą różnorodność zjawisk i przyczyn powodujących przypływ wody złożowej do odwiertu koniecznym staje się ich rozpoznanie szczególnie w przypadku wystąpienia nagłego i znacznego wzrostu wydobycia wody w czasie eksploatacji złoża węglowodorów danym odwiertem. Na podstawie wyników numerycznych symulacji me- 
chanizmów dopływu wody złożowej do odwiertów i ich weryfikacji na odwiertach eksploatacyjnych stwierdzono, że wykresy w układzie log-log wykładników woda-gaz (WWG), woda-ropa (WWR) w funkcji czasu wykazują odmienne kształty w zależności od sposobu dopływu wody do odwiertu, tj. stożkiem wodnym, wysoko przepuszczalną warstwą lub szczelinami w strefie przyodwiertowej. Wykres pierwszej pochodnej wykładnika wodno-gazowego (WWG') posiada dodatnie nachylenie w przypadku warstwowego przypływu wody złożowej do odwiertu, a uzyskuje ujemne nachylenie w przypadku dopływu wody w formie stożka. W przypadku uzyskania nagłego dopływu wody nachylenie wykresu zmienia się gwałtownie, osiaggając bardzo duże wartości (Seldal 1997; Chan 1995). Wykresy te stanowią komplet historii wydobycia i są prostym efektywnym narzędziem w diagnozowaniu problemu zawadniania odwiertu. Przykładowe kształty wykresów: wydobycia gazu ziemnego, zmian wykładnika wodno-gazowego i jego pierwszej pochodnej, dla wybranego odwiertu na jednym ze złóż gazu ziemnego w obszarze przedgórza Karpat, pokazano na rysunku 1.



Rys. 1. Zmiany średniej wydajności gazu,

wykładnika wodno-gazowego i jego pochodnej w czasie eksploatacji złoża gazu

Fig. 1. Changes in average gas production, water-gas ratio and its derivative during gas reservoir exploitation time

\section{Procedura porównawcza oceny skuteczności działania wybranych produktów typu RPM}

W Instytucie Nafty i Gazu w Krakowie (INiG-PIB) przeprowadzono cykl badań laboratoryjnych, mających na celu ocenę skuteczności działania kilku środków chemicznych 
klasyfikowanych jako środki RPM. Wybrano cztery produkty oznaczone literami A, B, C i D, potencjalnie przydatne (wg dystrybutorów) do zastosowania w planowanych zabiegach selektywnego ograniczania dopływu wody do odwiertów gazowych na przedgórzu Karpat. Jakkolwiek producenci środków RPM nie ujawniają szczegółowego składu chemicznego produktów, związki te możemy podzielić na dwie grupy: mikrożele (D) oraz sieciowane wysokocząsteczkowe polimery (A-C). Obie grupy środków RPM jak również mechanizmy ich działania zostały szczegółowo opisane we wcześniejszej pracy (Falkowicz i in. 2012). Badania prowadzone $\mathrm{w}$ termo-barycznych symulowanych warunkach złożowych polegały na zatłaczaniu do próbek piaskowca wybranego produktu i pomiaru zmian skutecznych przepuszczalności próbki dla wody (solanki) oraz dla gazu (azotu) przy nasyceniach rezydualnych. Procedura prowadzenia badań jak i używany sprzęt laboratoryjny są zbliżone lub identyczne ze stosowanymi $\mathrm{w}$ większości laboratoriów światowych i zostały detalicznie opisywane we wcześniejszych pracach (Dubiel i Falkowicz 2001, 2002). Testy laboratoryjne prowadzono na próbkach piaskowca szydłowieckiego tak, aby maksymalnie wiernie odwzorować zabieg selektywnego ograniczania dopływu wody złożowej do odwiertu gazowego. Próbki piaskowca miały kształt cylindrów o średnicy 0,0254 m (jeden cal) i długości około $0,05 \mathrm{~m}$. W trakcie testów laboratoryjnych stosowano ciśnienia uszczelnienia próbek piaskowca, których wartości odpowiadały wartościom ciśnienia skał nadkładu na głębokościach, gdzie występowały analizowane warstwy produkcyjne. To samo dotyczyło stosowanej temperatury (odpowiadała temperaturze złoża), dodatkowo tam gdzie to możliwe stosowano oryginalne płyny złożowe.

Wykonano łącznie około 30 testów wpływu poszczególnych produktów RPM na przepuszczalność początkową użytych rdzeni. Uśrednione wyniki testów dla każdego z produktów zamieszczono w tabeli $1 \mathrm{w}$ kolumnach 2 i 3 . W kolumnie 2 pokazano zmiany oznaczone symbolem $\Delta k_{s o l}$, oznaczające procentowy udział końcowej przepuszczalności względnej testowanej próbki skalnej dla solanki po zadziałaniu na próbkę cieczą RPM. Odpowiednio w kolumnie 3 (symbol $\Delta k_{g a z}$ ) zestawiono zmiany przepuszczalności względnej próbek piaskowca dla gazu. Opierając się na tych wielkościach obliczono wartości współczynnika skin-efektu (ang. skin-effect) oznaczany literą $S$. Wartość tego współczynnika bezpośrednio służy do ilościowej oceny wpływu zmian przepuszczalności skał strefy przyodwiertowej na wielkość produkcji odwiertu, tak w przypadku ropy jak też i gazu, względnie wody złożowej (solanki). Wielkość $S$ obliczano według zasady, aby w możliwie maksymalny sposób symulować warunki termobaryczne i złożowe (przepuszczalność skały, porowatość skały oraz rodzaj jej nasycenia $\mathrm{i}$ in.) występujące podczas realnego zabiegu RPM.

$$
S=\left(\frac{k_{0}}{k_{R P M}}-1\right) \cdot \ln \frac{r_{d}}{r_{w}}
$$

$\stackrel{\leftrightarrow}{\Delta} r_{d}-$ promień strefy przyodwiertowej o uszkodzonej przepuszczalności skał [m], 
$r_{w}-$ promień odwiertu eksploatacyjnego [m],

$k_{R P M}-$ przepuszczalność próbki(strefy przyodwiertowej) po zatłoczeniu cieczy RPM $[\mathrm{mD}]$,

$k_{0} \quad-$ przepuszczalność początkowa próbki (strefy przyodwiertowej) [mD].

W ramach założeń obliczeniowych przyjęto: $r_{d}=1,5 \mathrm{~m}, r_{w}=0,09 \mathrm{~m}$, a wartości $k_{R P M} \mathrm{i} k_{0}$ są wartościami przepuszczalności, odpowiednio po zabiegu RPM i przed tym zabiegiem, otrzymanymi w trakcie pomiarów laboratoryjnych. Obliczone wartości współczynnika $S$ dla przepływu przez próbkę solanki i gazu oznaczono odpowiednio przez $S_{s o l} ; S_{g a z}$ i ze-

Tabela 1. Wskaźniki efektywności technologicznej cieczy RPM

Table 1. Technical efficiency coefficient of RPM fluid

\begin{tabular}{|c|c|c|c|c|c|c|}
\hline Ciecz RPM & $\begin{array}{c}\Delta k_{\text {sol }} \\
{[\%]}\end{array}$ & $\begin{array}{c}\Delta k_{g a z} \\
{[\%]}\end{array}$ & $\begin{array}{c}S_{\text {sol }} \\
{[-]}\end{array}$ & $\begin{array}{c}S_{g a z} \\
{[-]}\end{array}$ & $\begin{array}{c}F E_{\text {sol }} \\
{[-]}\end{array}$ & $\begin{array}{c}F E_{\text {gaz }} \\
{[-]}\end{array}$ \\
\hline 1 & 2 & 3 & 4 & 5 & 6 & 7 \\
\hline $\mathrm{A}$ & 50,6 & 22,1 & 2,88 & 0,83 & 0,71 & 0,89 \\
\hline $\mathrm{B}$ & 36,4 & 1,9 & 1,61 & 0,06 & 0,81 & 0,99 \\
\hline $\mathrm{C}$ & 77,6 & 15,9 & 9,74 & 0,55 & 0,42 & 0,93 \\
\hline $\mathrm{D}$ & 89,5 & 49,3 & 24,10 & 2,85 & 0,23 & 0,71 \\
\hline
\end{tabular}

stawiono w tabeli 1 (kolumna 4 i 5).

Po pewnym czasie po wykonaniu zabiegu RPM eksploatacja złoża odbywa się w tzw. warunkach pseudoustalonych, a produkcja wody przez odwiert spada z poziomu $q_{w i}$ do poziomu $q_{w d}$, co jest bezpośrednim oczekiwanym skutkiem zabiegu RPM. W tym przypadku iloraz tych wartości tzw. wskaźnik FE (Flow Efficiency) charakteryzuje skuteczność zabiegu RPM i można go przedstawić w postaci:

$$
F E=\frac{q_{w d}}{q_{w i}}=\frac{\ln \left(\frac{r_{e}}{r_{w}}\right)-0,75}{\left[\ln \left(\frac{r_{e}}{r_{w}}\right)-0,75+S\right]}
$$

$\stackrel{\leftrightarrow}{\mu_{e}} \quad-$ promień strefy drenażu odwiertu $[\mathrm{m}]$,

$r_{w} \quad-$ promień odwiertu eksploatacyjnego [m],

$q_{w d}$ - natężenie wypływu gazu z odwiertu po zabiegu RPM $\left[\mathrm{m}^{3} / \mathrm{s}\right]$,

$q_{w i} \quad$ natężenie wypływu gazu z odwiertu przed zabiegiem RPM $\left[\mathrm{m}^{3} / \mathrm{s}\right]$. 
Zakładając, że wartość promienia drenażu odwiertu $r_{e}$ najczęściej mieści się w przedziale 200-400 metrów, korzystając z własności funkcji logarytmicznej, na potrzeby tych obliczeń szacunkowych, wyrażenie (2) można przedstawić w postaci:

$$
F E=\frac{q_{w d}}{q_{w i}}=\frac{7}{7+S}
$$

W sensie fizycznym wartość wskaźnika FE informuje o technologicznej skuteczności zabiegu. I tak, w przypadku wody złożowej, im jego wartość jest mniejsza, tym zabieg był bardziej skuteczny. Jakkolwiek celem zabiegu RPM jest minimalizacja dopływu wody złożowej do odwiertu, w praktyce produkcja węglowodorów (w tym przypadku gazu) również ulega obniżeniu. W tabeli $1 \mathrm{w}$ kolumnach 6 i 7 podano wyliczone wielkości wskaźnika FE dla gazu i wody złożowej, bazując na uzyskanych uprzednio wynikach pomiarów laboratoryjnych. Wskaźniki te dla hipotetycznego zabiegu uzyskano zakładając jednakowy, równy 1,5 metra promień inwazji cieczy RPM tak w strefę gazonośna, jak i zawodnioną. W praktyce przemysłowej sytuacja taka będzie się zdarzała niezmiernie rzadko.

Analizując uzyskane wyniki badań (tab. 1) można stwierdzić, że w przypadku wszystkich badanych produktów (A-D) znacznemu obniżeniu przepuszczalności względnej próbki piaskowca dla wody złożowej (36-90\%) zawsze towarzyszy stosunkowo mniejsze obniżenie przepuszczalności względnej próbki piaskowca dla gazu (2-49\%). Z tabeli 2 wynika, że produkt B należy zastosować w takich odwiertach, w których tylko w minimalnym stopniu można ograniczyć produkcję gazu, aby była ona dalej opłacalna. Natomiast jeżeli akceptowalnym jest spadek produkcji gazu na poziomie ponad $20 \%$ należy zastosować produkt $\mathrm{D}$, jednocześnie uzyskując znacząco efektywny spadek produkcji solanki na poziomie $80 \%$ jej pierwotnej produkcji.

Zabiegi typu RPM zaleca się stosować w tych odwiertach wydobywczych, w których z różnych przyczyn nie ma technicznych możliwości zatłoczenia cieczy zabiegowej tylko do zawodnionej warstwy złoża. Prawidłowo dobrana ciecz RPM w dużo większym stopniu penetruje warstwę wodonośną niż warstwę gazonośną (tzw. efekt zabiegu RPM), co wynika m.in. z różnicy w chłonności obu stref. Sytuację tę schematycznie pokazano na rysunku 2.

W większości przypadków, w zabiegach typu RPM, objętość niezbędnej do przeprowadzenia zabiegu cieczy roboczej wylicza się przyjmując 1,5 metra jako głębokość (promień strefy drenażu odwiertu) zatłoczenia cieczy w strefę o perforowanej okładzinie odwiertu. Uwzględniając powyższe i zakładając dla uproszczenia, że strefy produktywne mają równe miąższości i porowatości, podano wartości współczynnika FE (wyrażonego procentowo) dla przypadków, gdy w trakcie zabiegu do strefy gazonośnej zatłoczono odpowiednio: $10 \%$, $20 \%, 30 \%, 40 \%$ i $50 \%$ objętości użytej w zabiegu cieczy. Podział ten wynika z różnic w przepuszczalności strefy gazonośnej i zawodnionej i co do wartości jest zgody z ilorazem przepuszczalności skutecznych obu stref.

Uwzględniając powyższe założenia można wyliczyć głębokość zatłoczenia produktu do każdej ze stref, a korzystając z zależności (1) i (2), można ocenić wielkość spadku produkcji 


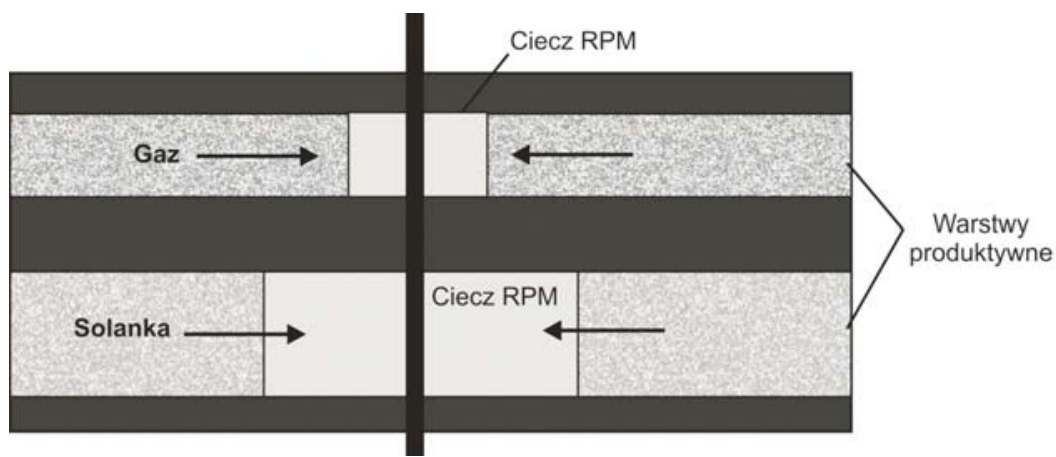

Rys. 2. Idea zabiegu RPM

Fig. 2. Idea of RPM treatment

Tabela 2. Wartość współczynnika FE w zależności od przepuszczalności warstw gazonośnej i wodonośnej

Table 2. FE coefficient value in dependence on gas and water zones permeability ratio

\begin{tabular}{|c|c|c|c|c|c|c|c|c|c|c|}
\hline \multirow{2}{*}{$\begin{array}{c}\text { Ciecz } \\
\text { RPM }\end{array}$} & \multicolumn{6}{|c|}{ Udział procentowy przepuszczalności warstwy gazonośnej do zawodnionej [\%] } \\
\cline { 2 - 12 } & \multicolumn{2}{|c|}{10} & \multicolumn{2}{|c|}{20} & \multicolumn{2}{|c|}{30} & \multicolumn{2}{|c|}{40} & \multicolumn{2}{|c|}{50} \\
\hline & gaz & solanka & gaz & solanka & gaz & solanka & gaz & solanka & gaz & solanka \\
\hline 1 & 2 & 3 & 4 & 5 & 6 & 7 & 8 & 9 & 10 & 11 \\
\hline A & 92,07 & 68,78 & 90,92 & 69,22 & 90,23 & 69,64 & 89,75 & 70,19 & 89,41 & 70,88 \\
\hline B & 99,41 & 79,80 & 99,32 & 80,12 & 99,26 & 80,44 & 99,22 & 80,84 & 99,20 & 81,36 \\
\hline C & 94,59 & 39,47 & 93,78 & 39,95 & 93,29 & 40,44 & 92,95 & 41,06 & 92,70 & 41,88 \\
\hline D & 77,22 & 20,86 & 74,52 & 21,19 & 72,93 & 21,53 & 71,88 & 21,97 & 71,13 & 22,55 \\
\hline
\end{tabular}

każdej ze stref wyrażonego współczynnikiem FE. Na podstawie danych zamieszczonych w tabeli 2 można stwierdzić, że pożądany technologicznie efekt RPM jest tym większy im wyższa jest skuteczność zastosowanej cieczy zabiegowej i większa różnica w głębokości penetracji cieczy RPM do strefy zawodnionej i gazonośnej. Wielkości współczynnika FE podane w tabeli 2 (w kolumnach 10 i 11) są identyczne co do wartości z wartościami współczynnika RPM zamieszczonymi w kolumnie 6 i 7 tabeli 1. Wynika to z faktu przyjęcia do obliczeń ekwiwalentu (równoważności) wartości przepuszczalności strefy zawodnionej i gazonośnej. Dane zamieszczone w tabeli 2 umożliwiają porównanie skuteczności technologicznej poszczególnych cieczy RPM dla tego samego złoża/odwiertu. 


\section{Wyniki badań reologii wybranych cieczy zabiegowych}

Jak już wspomniano zabieg typu RPM polega na zatłoczeniu cieczy zabiegowej na określoną głębokość w strefę produktywną, aby ograniczyć produkcję wody przez odwiert. Zatłoczenie cieczy zabiegowej można zrealizować za pomocą elastycznego przewodu Coiled Tubing (CT) lub rurek wydobywczych. W praktyce przemysłowej najczęściej stosowane wydajności tłoczenia cieczy zabiegowej mieszczą się w granicach $5-10 \mathrm{~m}^{3} / \mathrm{godz}$. Prędkość ścinania dla tej cieczy w rurach wydobywczych o średnicy nominalnej $23 / 8$ " (średnica wewnętrzna $d=50,67 \mathrm{~mm}$ ), przy wydajności tłoczenia $5-10 \mathrm{~m}^{3} /$ godz. mieści się w przedziale 130-260 s ${ }^{-1}$. Przeprowadzono pomiary lepkości dynamicznej testowanych cieczy, a zmiany współczynnika lepkości dynamicznej w funkcji prędkości ścinania dla cieczy A oraz B pokazano na rysunkach 3 i 4.

Analizując rysunki można zauważyć nieznaczne zmiany współczynnika lepkości dynamicznej obu cieczy w badanym zakresie szybkości ścinania. Na potrzeby oceny technicznych i hydraulicznych warunków tłoczenia cieczy do złoża można przyjąć, że obie ciecze mają charakter cieczy newtonowskich. Wartości współczynnika lepkości dynamicznej każdej z badanych cieczy różniły się nieznacznie, jakkolwiek były stosunkowo niskie w porównaniu do współczynników lepkości większości płynów technologicznych stosowanych w przemyśle tak na etapie poszukiwania złóż, jak też wydobycia węglowodorów.

Do dalszych obliczeń przyjęto średnie wartości współczynnika lepkości dla cieczy A i cieczy B, które wyniosły odpowiednio $\mu_{\mathrm{A}}=1,97 \mathrm{mPa} \cdot \mathrm{s}$ oraz $\mu_{\mathrm{B}}=3,95 \mathrm{mPa} \cdot \mathrm{s}$. Straty ciśnienia na pokonanie oporów hydraulicznych podczas zatłaczania danej cieczy zabiegowej przez przewód tłoczny w znacznej mierze zależą od średnicy wewnętrznej tego przewodu

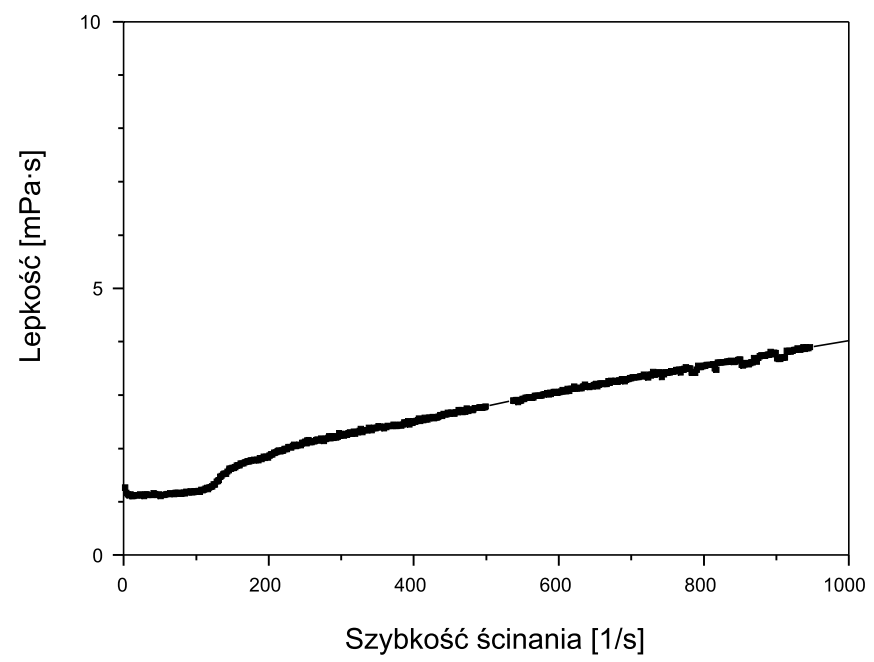

Rys. 3. Zależność lepkości pozornej cieczy zabiegowej A od szybkości ścinania

Fig. 3. Dependence of apparent viscosity of the analysed fluid A on shear rate 




Rys. 4. Zależność lepkości pozornej cieczy zabiegowej B od szybkości ścinania

Fig. 4. Dependence of apparent viscosity of the analysed fluid B on shear rate

i współczynnika lepkości dynamicznej cieczy oraz wydatku jej tłoczenia. Dla porównania, na rysunkach 5 i 6 przedstawiono wyniki obliczeń jednostkowych oporów przepływu cieczy zabiegowych A i B w przewodzie o średnicy wewnętrznej 50,1 mm oraz $62,0 \mathrm{~mm}$, przy założonych wydatkach zatłaczania cieczy wynoszacych od $2,5 \mathrm{~m}^{3} /$ godz. do ponad $35 \mathrm{~m}^{3} /$ godz. W obliczeniach pominięto wpływ zmian temperatury w odwiercie wraz z głębokością na zmiany oporów hydraulicznych tłoczonej do złoża cieczy zabiegowej.

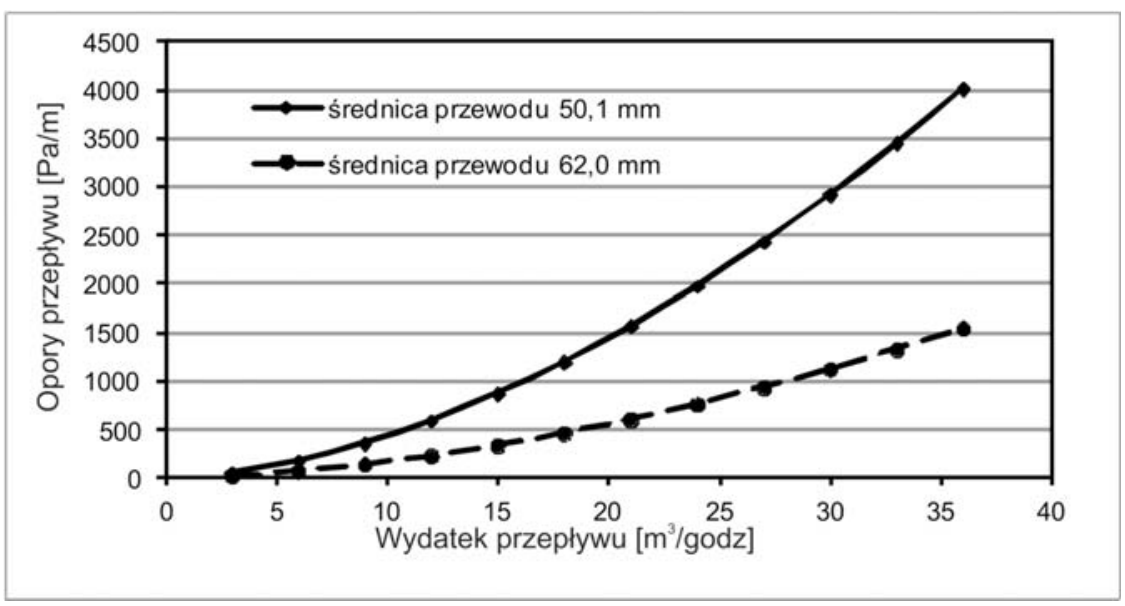

Rys. 5. Opory hydrauliczne przepływu cieczy zabiegowej A w zależności od wydatku tłoczenia

Fig. 5. Hydraulic resistance of fluid A flow in dependence on injection rate 


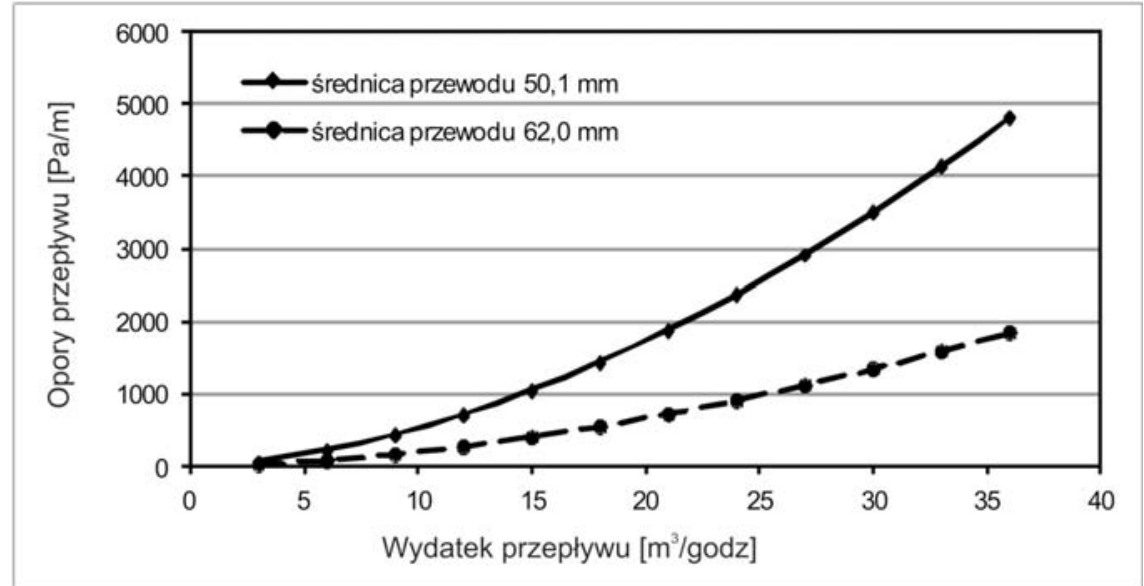

Rys. 6. Opory hydrauliczne przepływu cieczy zabiegowej B w zależności od wydatku tłoczenia

Fig. 6. Hydraulic resistance of fluid B flow in dependence on injection rate

\section{Podsumowanie}

Testowane ciecze RPM są wodnymi roztworami polimerów i są one (wg deklaracji producentów) niepalne, nieagresywne chemicznie i praktycznie obojętne dla środowiska naturalnego. Dodatkowo, uwzględniając ich charakterystyki reologiczne, można stwierdzić, że z technicznego punktu widzenia zabiegi RPM są zabiegami stosunkowo prostymi i nie zagrażają środowisku naturalnemu. Niskie opory hydrauliczne tłoczenia cieczy nie wymagają zaangażowania wysoko specjalistycznego sprzętu, co czyni te zabiegi stosunkowo tanimi. W gospodarce rynkowej o celowości stosowania takiej lub innej technologii przesądza rachunek ekonomiczny. Przesłanką do zastosowania technologii RPM jest ograniczenie produkcji wody w wydobywczych odwiertach gazowych, a tym samym ograniczenie kosztów jej utylizacji, jak i utrzymanie produktywności odwiertów na opłacalnym poziomie, gdyż zazwyczaj wzrastająca produkcja wody ogranicza produkcję gazu. Tak więc koszty zastosowania technologii RPM powinny się zbilansować z oszczędnościami osiagniętymi z obniżenia kosztów zagospodarowania mniejszej ilości wydobytej wody złożowej.

$\mathrm{Na}$ koniec należy zauważyć, że procedura laboratoryjnej oceny skuteczności oddziaływania dostępnych na rynku środków typu RPM służy najczęściej tylko analizie porównawczej. Bowiem podczas procesu eksploatacji złoża węglowodorów, oprócz występujących zmiennych warunków złożowych, następują również zmiany wysokości słupa wody złożowej w odwiercie, powodujące zmniejszenie wartości depresji ciśnienia, a tym samym zmniejszenie produkcji węglowodorów. 


\section{Wnioski końcowe}

1. W światowym górnictwie ropy i gazu coraz większą wagę przywiązuje się do selektywnego ograniczenia dopływu wody złożowej do odwiertów wydobywczych ropnych i gazowych, poprzez stosowanie zabiegów typu RPM.

2. Na podstawie przedstawionych w niniejszej publikacji wyników badań laboratoryjnych wykonanych w INiG-PIB w Krakowie można stwierdzić, że wszystkie przebadane produkty (A-D) mogą mieć zastosowanie w zabiegach typu RPM w odwiertach wydobywczych gazu ziemnego. Produkt B zaleca się stosować, tam gdzie ze względów ekonomicznych tylko w minimalnym stopniu można ograniczyć produkcję gazu. Natomiast jeżeli akceptowalnym jest spadek produkcji gazu na poziomie ponad $20 \%$ należy zastosować produkt $\mathrm{D}$, uzyskując jednocześnie spadek produkcji solanki na poziomie $80 \%$.

3. Opracowana przez autorów procedura laboratoryjnej oceny skuteczności działania dostępnych na rynku produktów typu RPM, może stanowić podstawę ich wyboru dla potrzeb przemysłowych, z równoczesnym uwzględnieniem warunków złożowych, eksploatacyjnych oraz ekonomicznych. Wstępnie oceniono, że badane produkty RPM mogą być zastosowane z dużym powodzeniem w odwiertach wydobywczych gazu ziemnego na przedgórzu Karpat.

\section{Podziękowania}

Autorzy artykułu pragnq podziękować dr. inż. Piotrowi Kaszy i mgr. inż. Józefowi Suchowi z Instytutu Nafty i Gazu Oddz. Krosno za ich znaczacy wklad w przygotowanie niniejszego artykutu i cenne wskazówki, jakie wnieśli na etapie jego przygotowania

\section{LITERATURA}

Chan, K.S. 1995. Water Control Diagnostic Plots. SPE Annual Technical Conferences and Exhibition, Dallas 22-25 październik 1995, s. 755-763.

Curtice, R. i Dalrymple, E. 2004. Just the cost of doing business? World Oil Magazine 225 (10), s. 77-78.

Dovan, H.T. i Hutchins, R.D. 1994. New Polymer technology for Water Control in Gas Well. SPE Production \& facilities, SPE 26653.

Dubiel, S. i Falkowicz, S. 2001. Wpływ płuczek wiertniczych zasolonych i solanek na zmiany piaskowców gazonośnych w świetle badań laboratoryjnych. Archives of Mining Sciences PAN 46 (3), s. 357-374.

Falkowicz, S. i Dubiel, S. 2002. Badanie wpływu płuczek wiertniczych na przepuszczalność skał zbiornikowych miocenu autochtonicznego Przedgórza Karpat. Wiertnictwo, Nafta, Gaz (rocznik AGH) t. 19/1.

Falkowicz i in. 2009 - Falkowicz, S., Cicha-Szot, R., Dubiel, S. i Bailey, S. 2009. Biokatalizowany żel krzemianowy w procesach eksploatacji złóż ropy naftowej i wód geotermalnych. Gospodarka Surowcami Mineralnymi - Mineral Resources Management 25(4), s. 5-22.

Falkowicz i in. 2012 - Falkowicz, S., Dubiel, S. i Cicha-Szot, R. 2012. Problemy ograniczania dopływu wody do odwiertów wydobywczych gazowych i ropnych. Gospodarka Surowcami Mineralnymi-Mineral Resources Management 28(1), s. 125-136. 
Gutierrez i in. 2007 - Gutierrez, M., Saravia, C. i Eoff, L. 2007. Advanced Technology to Reduce Water Production in Gas Wells. ACIPET XII Congreso Colombiano de Petroleo y Gas, Bogota D.C., Kalumbia, 23-26 październik 2007.

Ligthelm, D.J. 2001. Water Shut Off in Gas Wells:Is there Scope for Chemical Treatment? SPE European Formation Damage Conference, Haga, Holandia, 21-22 maj 2001.

Mannella A. i in. 1999 - Mannella, A., Chiappa, L. i Lockhart T.P. 1999. Candidate and Chemical Selection Rules for Water Shuttoff Polymer Treatments. SPE European Formation Damage Conference, Haga, Holandia 31 maj-1 czerwiec 1999

Pusch, G. i in. 1995 - Pusch, G., Kohler, N. i Kretzschmar H.J. 1995. Practical Experience with Water Control in Gas Wells by Polymer Treatments. 8 th European IOR - Symposium in Vienna, Austria, 15-17 maj 1995.

Ranjbar, M. i Kohler, N. 1993. Selective control of water production in gas wells. $14^{\text {th }}$ IEA Collaborative Project in Enhanced Oil Recovery, Salzburg Austria, 17-21 październik 1993.

Ranjbar i in. 1995 - Ranjbar, M., Czolbe, P. i Kohler N. 1995. Comparative Laboratory Selection and Field Testing of Polymers for Selective Control of Water Production In Gas Wells. SPE International Symposium on Oilfield Chemistry, San Antonio, Texas, 14-17 luty 1995, SPE 28984.

Rousseau i in. 2005 - Rousseau, D., Chauveteau, G., Renard, M., Tabary, R., Zaitoun, A., Mallo, P., Braun, O i Omari A. 2005. Rheology and Transport in Porous Media of New Water Shutt Off Conformance control Microgels. International Symposium on Oilfield Chemistry, Houston, Teksas, USA 2-4.02, SPE 93245.

Seldal, M. 1977. Using Water/Oil Ratios to Diagnose Excessive Water Production Mechanisms. Master of Science Thesis. New Mexico Institute of Mining and Technology.

Tielong, C. i in. 1998 - Tielong, C., Yong, Z., Kezong, P. i Wanfeng, P. 1998. Experimental Studies and Field Trials of Relative Permeability Modifier for Water Control of Gas Wells In Low Permeability Reservoir. Gas Technology Conference, Calgary, Alberta, Canada, 28 kwiecień-1 maj 1998.

Zaitoun i in. 1992a - Zaitoun, A., Kohler, N., Maitin, B.K. i Truchetet R. 1992a. Selective Control of Water Production in Oil or Gas Producing Wells. Oil and Gas in a Wider Europe, $4^{\text {th }}$ EC Symposium, Berlin.

Zaitoun, A. i in. 1992b - Zaitoun, A., Kohler, N. i Maitin, B.K. 1992b. Preparation of a water control polymer treatment at conditions of high temperature and salinity. Journal of Petroleum science and Engineering, 7 , s. $67-75$

Zaitoun i in. 1999 - Zaitoun, A., Kohler, N., Bossie-Codreanu, D. i Denys K. 1999. Water Shutoff by Relative Permeability Modifiers: Lessons from Several Field Applications. Annual Technical Conference and Exhibition Houston, Texas, 3-6 październik, SPE 56740.

Zaitoun, A. i Pichery, T. 2001. A Succesful Polymer treatment For Water Coning Abatement in Gas Storage Reservoir. Annual Technical Conference and Exhibition, Nowy Orlean, Luizjana, USA 30.09-03.10.2001, SPE 71525.

Zaitoun i in. 2007 - Zaitoun, A., Tabary, R., Rousseau, D., Pichery, T., Nouyoux, S., Mallo P., i Braun O. 2007. Using Microgels to Shutt Off water in Gas Storage Well. International Symposium on Oilfield Chemistry, Houston, Teksas, USA 28.02-2.03.2007, SPE 106042. 
Słowa kluczowe

ograniczanie dopływu wody złożowej, eksploatacja złóż gazu ziemnego, zabiegi RPM, charakterystyka reologiczna, polimery, mikrożele

\section{Streszczenie}

W publikacji przedstawiono procedury doboru i oceny skuteczności technologicznej środków chemicznych stosowanych w zabiegach selektywnego ograniczania dopływu wody złożowej do odwiertów wydobywczych gazu ziemnego. W zabiegach, nazywanych dalej zabiegami RPM (od angielskiego Relative Permeability Modification), wykorzystuje się zjawisko zmniejszania przepuszczalności względnej skał zbiornikowych dla wody po zatłoczeniu do nich specjalnych środków chemicznych zwanych produktami RPM. Na podstawie danych literaturowych opisano efekty kilku zabiegów typu RPM wykonanych w ostatnich latach w zawodnionych odwiertach gazowych na złożach o różnych parametrach geologiczno-eksploatacyjnych. Przeprowadzono analizę danych eksploatacyjnych kilku odwiertów gazowych pod kątem zasadności stosowania w tych odwiertach zabiegów typu RPM. Przedstawiono sposób oceny charakteru przypływu wody do odwiertu (stożkiem lub warstwowy), co ma podstawowe znaczenie przy wyborze odwiertu do zabiegu typu RPM. Oceny charakteru przypływu wody do odwiertu dokonano metodą graficznej analizy zmian przebiegu wykresu zależności pierwszej pochodnej wykładnika wodno-gazowego od czasu eksploatacji złoża gazu danym odwiertem. Przedstawione w układzie podwójnie logarytmicznym kształty tych wykresów stanowią podstawę rozróżnienia charakteru dopływu wody złożowej do odwiertu gazowego oraz doboru technologii zabiegu RPM.

Opierając się na danych producentów, wybrano cztery komercyjne środki typu RPM, które przetestowano laboratoryjnie realizując zabiegi RPM w symulowanych warunkach złożowych. Realizując testy laboratoryjne, uwzględniono specyficzne właściwości dostępnych na rynku środków chemicznych (polimery lub mikrożele), odmienny mechanizm zmian przepuszczalności względnej skały kolektorskiej dla wody złożowej oraz charakterystykę eksploatacyjną odwiertów wydobywczych gazu ziemnego na przedgórzu Karpat. Na podstawie uzyskanych danych laboratoryjnych i zaproponowanej procedury, dokonano oceny skuteczności technologicznej każdego z wytypowanych produktów, w przypadku ich zastosowania w zawodnionych odwiertach produkujących gaz ziemny.

W zakresie analizy doboru parametrów technologicznych zabiegu RPM wykonano obliczenia umożliwiające porównanie wartości strat ciśnienia na pokonanie oporów hydraulicznych przepływu dwóch cieczy zabiegowych o różnym współczynniku lepkości dynamicznej przez przewody zatłaczające o różnej średnicy, w zależności od wydatku zatłaczania. Uwzględniono przy tym charakterystyki reologiczne wyznaczone laboratoryjnie dla tych wytypowanych produktów. 


\title{
COMPARATIVE LABORATORY TESTS OF PRODUCTS FOR SELECTIVE CONTROL OF WATER IN GAS WELLS
}

\author{
Key words
}

water shut-off, gas field exploitation, RPM treatments, rheological characteristic, polymers, microgels

Abstract

This paper presents selection procedures and technological efficiency evaluation of chemical agents applied for the selective water shut-off treatments in gas production wells. This treatments exploit the phenomenon of selective modification of rock permeability to water without impairing that to gas by injection into a producing well water soluble chemicals (Relative Permeability Modifiers RPMs), mainly polymers, alkaline and surfactants.

During last years, there have been several RPM treatments performed in the reservoirs with distinct geological and exploitation parameters which effects were characterized based on literature data. Taking into consideration previous experiences, analysis of exploitation data of several wells for RPM treatment application was performed. Fundamental importance during well selection have the way of determination of water flow (coning or layer) to well. That evaluation was performed using the method of graphical analysis of changes in the first order derivative of water-gas ratio from exploitation time of gas reservoir by particular well. The shape of the curve presented in log-log scale form the basis of distinction the nature of water flow to gas well and selection RPM treatment technology.

Based on the data provided by manufacturers four commercial RPM agents were chosen and tested in the laboratory under simulated downhole reservoir conditions. Conducting tests specific properties of available on the market RPM agents (polymer or microgels), various mechanism of relative permeability reduction of collector rock for formation water and Carpathian foothills gas wells exploitation characteristics were taking into consideration.

Furthermore, this study outlines analysis of the technological parameters selection based on calculation which allows to compare the value of pressure drop needed to overcome the hydraulic resistance of flow two RPM agents with different dynamic viscosity coefficients by the injection line with various diameter and depending on flow rate. 
